\title{
STRATEGI KOMUNIKASI RADIO DALKA FM MEULABOH DALAM DALAM MENINGKATKAN JUMLAH PEMASANG IKLAN
}

\author{
Rahma Hidayati ${ }^{1)}$, Triyanto $^{2)}$, Masmidar ${ }^{3)}$ \\ ${ }^{1)}$ Program Studi Ilmu Komunikasi, Fakultas Ilmu Sosial dan Ilmu Politik \\ Universitas Teuku Umar \\ Email: rahmahidayati32@gmail.com \\ ${ }^{2)}$ Program Studi Ilmu Sosiologi, Fakultas Ilmu Sosial dan Ilmu Politik \\ Universitas Teuku Umar \\ Email: triyanto@utu.ac.id \\ ${ }^{3)}$ Program Studi Ilmu Komunikasi, Fakultas Ilmu Sosial dan Ilmu Politik \\ Universitas Teuku Umar
}

\begin{abstract}
This research concludes that, Pull Strategy applied by Dalka FM is by looking for target of advertiser candidate, then send Dalka FM radio profile which inside is designed as possible. Another strategy is to include the price of the ad. It is intended that the advertiser becomes interested in contacting and responding to the offer letter, or by visiting the prospect's business premises or face to face immediately and approaching to offer direct advertising. Push Strategy to encourage advertiser interest into a desire to work together by providing spot bonuses or views for advertisers. Pass Strategy to expand marketing and create public opinion and positive image by holding events on air and off air, held events in the form of field activities to get closer to the community.
\end{abstract}

Keywords: Communication Strategy, Dalka FM Radio, Advertisement.

\section{PENDAHULUAN}

Latar Belakang

Radio merupakan salah satu unit usaha besar yang penuh persaingan mulai pada tahu 1920 hingga sekarang.Radio saling berkompetisi untuk memperebutkan pendengar dan pengiklan (Usman, 2009, h.103).Hal tersebut merupakan faktor penentu bertahannya stasuin radio sehingga setiap stasiun radio dituntut untuk bisa menarik pendengar dan pengiklan melalui pemasarannya.

Radio tidak hanya menyampaikan informasi bahkan radio hadir memasuki setiap sudut kehidupan didunia, menawarkan hiburan musik yg terbaru bagi masyarakat kota, ataupun menyampaikan informasi bagi masyarakat pedesaan yg jauh terpencil (Muhtadi, 1999, h.96). dengan demikian radio menjadi media yang digemari masyarakat karena memiliki fungsi sebagai media yang informatif, edikatif dan persuasif (Effendy, 1993, h.300).

Radio komersial selain sebagai media yang menjadi sumber informasi, pendidikan dan hiburan bagi masyarakat, juga berdiri untuk meraih pendengar sebanyak-banyaknya sehingga menarik banyak pengiklan menggunakan media radio untuk mengiklankan produk mereka kepada masyarakat (Morissan, 2011, h.88-89). 
Tabel 1.1

Jumlah Radio yang ada di Meulaboh

\begin{tabular}{|l|l|}
\hline Nama Radio & Frekuensi \\
\hline RRI Pro 1 & 97,0 \\
\hline RRI Pro 2 & 90,3 \\
\hline Dalka FM & 101,3 \\
\hline Fas FM & 103,7 \\
\hline Rasati FM & 96,0 \\
\hline
\end{tabular}

(sumber data, fauzilaksya.blogspot.co.id,2017)

Berdasarkan tabel diatas jumlah dan frekuensinya radio di Aceh Barat ada lima radio, tetapi di penelitian hanya meneliti diradio Dalka FM.

\section{Rumusan Masalah}

Berdasarkan latar belakang masalah yang telah dipaparkan diatas, maka rumusan dalam penelitian ini adalah bagaimana strategi komunikasi marketing radio dalka FM dalam meningkatkan jumlah pemasang iklan?

\section{Tujuan Penelitian}

Tujuan penelitian ini adalah untuk mengetahui strategi komunikasi marketing radio dalka FM Meulaboh dalam meningkatkan jumlah pemasang iklan.

\section{Manfaat Penelitian}

Manfaat penelitian ini dapat dibagi menjadi dua secara teoritis dan praktis adalah sebagai berikut:

\section{Manfaat Teoritis}

Melalui penelitian ini diharapkan dapat memberi sumbangan pemikiran dan memperkaya perbendaharaan kepustakaan bagi pengembangan ilmu pengetahuan pada umumnya dan bagi jurusan Ilmu Komunikasi khususnya berkaitan dengan strategi kominikasi radio Dalka FM dalam mendapatkan jumlah pemasang iklan serta sebagai masukan kepada peneliti mendatang.

\section{ManfaatPraktis}

Hasil penelitian ini diharapkan dapat berguna bagi media dan internal, untuk wartawan dan praktisi sebagai bahan informasi.

\section{KAJIAN PUSTAKA}

\section{Strategi Komunikasi}

Menurut Rangkuti $(2009$, h.3) strategi adalah alat untuk mencapai tujuan.Tujuan utamanya adalah agar perusahaan dapat melihat secara objektif kondisi-kondisi internal dan eksternal, sehingga perusahaan dapat mengantisipasi perubahan lingkungan eksternal.Dalam hal ini dapat dibedakan secara jelas fungsi manajemen, konsumen, distributor, dan pesaing.Jadi, perencanaan strategis penting untuk memperoleh keunggulan bersaing dan memiliki produk yang sesuai dengan keinginan konsumen dengan dukungan yang optimal dari sumber daya yang ada.Untuk memahami konsep perencanaan strategis, kita perlu memahami pengertian konsep mengenai strategi.

Strategi merupakan penetapan sasaran organisasi dengan mengingat kekuatan eksternal dan internal, perumusan kebijakan tertentu untuk mencapai sasaran dan memastikan implementasinya secara tetap sehingga tujuan dan sasaran utama akan tercapai. Dari pengertian- 
pengertian diatas dapat disimpulkan bahwa strategi adalah suatu cara atau taktik yang digunakan untuk mencapai tujuan perusahaan. Hal ini dapat dilakukan dengan mengadakan perbaikanperbaikan, mengatasi kelemahan-kelemahan, sehingga aktivitas dan perkembangan perusahaan dapat berkelanjutan (George. A Steiner, 2008, h.18)

Komunikasi adalah suatu proses dimana seorang individu (komunikator) menyampaikan stimulan (rangsangan) yang bisa berbentuk pesan atau lambang untuk merubah perilaku orang lain kearah sikap dan tindakan yang diinginkan oleh komunikator. Komunikasi adalah proses mengirimkan berita diantara pihak-pihak yang saling berhubungan sehingga daripadanya diperoleh pemahaman tentang apa yang dimaksud satu sama lain (imam dan siswandi, 2007. h.151).

Strategi komunikasi pada hakekatnya adalah perencanaan (planning) dan manajemen (managemen) untuk mencapai suatu tujuan.Untuk mencapai tujuan tersebut strategi tidak berfungsi sebagai peta jalan yang hanya menunjukkan arah saja, melainkan harus menunjukkan bagaimana taktik operasionalnya.Strategi komunikasi merupakan paduan dari perencanaan komunikasi dan manajemen komunikasi untuk mencapai suatu tujuan (Effendy, 2003, h.300).

\section{Komunikator}

Menurut Hafied Cangara (2006, h.39) memberikan pengertian komunikator (communicator) / pembicara (speaker) yaitu pemrakarsa komunikasi (pembawa berita) bisa individu, keluarga maupun kelompok yang mengambil inisiatif dalam penyampaian gerakan komunikasi. Komunikasi ini berlangsung antar individu atau kelompok lain yang menjadi sasarannya. Komunikator dapat juga berarti tempat berasalnya sumber komunikasi.Senada dengan pandangan (Nurjaman dan Umam, 2012, h.36-38). Yang menjelaskan komunikator adalah orang yang menyatakan pesan kepada komunikasn yang dapat berupa perseorangan atau kelompok. Lebih lanjut penjelasan (Effendy, 2011, h.18) yang menyatak sender atau disebut komunikator adalah unsur yang menyampaikan pesan kepada seseorang atau sejumlah orang.

\section{Komunikan}

Penerima biasa disebut dengan istilah khalayak, sasaran, pembaca, pendengar, pemirsa, audince, decoder atau komunikan. Khalayak adalah salah satu aktor dari proses komunikasi. Karena itu unsur khalayak tidak boleh diabaikan, sebab berhasil tidaknya suatu proses komunikasi sangat ditentukan oleh khalayak. Penerima dalam studi komunikasi bisa berupa individu, kelompok dan masyarakat. Mejadi tugas seorang komunikator untuk mengetahui siapa yang akan menjadi khalayak sebelum proses komunikasi berlangsung (Cangara, 2006, h.171), komunikan dalam penelitian ini adalah Thya Mahotra dari Thya Salon, Samsuar dari Nagan Raya Fashion, Fitra dari JNE, M.Nasir dari BAKOPI, Mega dari Hoki Selular.

\section{Pesan}

Menurut Hafied Cangara (2006, h.39) pesan atau berita (message) adalah berita yang disampaikan atau dibicarakan oleh komunikator melalui lambang-lambang, pembicaraan gerakan dan sebagainya. Message bisa berupa gerakan, sinar, suara, lambaian tangan, kibaran bendera atau tanda-tanda lain, dengan interpretasi yang tepat akan arti dan makna tertentu. Menurut Effendy (2011, h.18) dalam penjelasnnya menyatakan bahwa pesan (message) adalah seperangkat lambang yang mempunyai makna yang disampaikan oleh komunikator.

\section{Media}

Menurut Nurjaman dan Umam (2012, h.36-38) menjelaskan bahwa saluran/media (channel) adalah jalan yang dilalui oleh isi pernyataan komunikator kepada komunikan yang digunakan oleh pengirim pesan. 


\section{Radio}

Radio adalah teknologi yang digunakan untuk mengirimkan sinyal dengan cara modulasi dan radiasi elektromagnetik (gelombang elektromagnetik). Gelombang ini melintas dan merambat lewat udara dan juga bisa merambat lewat ruang hampa udara, karena gelombang ini tidak memerlukan medium atau pengangkut. Radio juga merupakan salah satu bentuk dari komunikasi massa. Melalui radio suatu komunikasi yang akan disampaikan oleh komunikator kepada khalayak banyak dapat berlangsung dalam waktu yang singkat dan komunikan akan menerima komunikasi secara bersamaan walaupun ditempat yang berbeda. Radio adalah salah satu pilihan media hiburan dan informasi ternyata tidak kalah pamor dengan media cetak maupun elektronik, info kesehatan, teknologi, gaya hidup, info seni dan budaya, berita politik, ekonomi, kriminalitas, agama bahkan gosip artis bisa didengar secara gratis dari subuh hingga tengah malam. (Asep, 2009, h.21).

\section{Model Threeways Strategy}

Strategi komunikasi merupakan sasaran organisasi dengan mengingat kekuatan eksternal dan internal, perumusan kebijakan tertentu untuk perencanaan dan manajemen dalam mencapai tujuan. Dari konsep Marketing Public Relations secara garis besarnya terdapat tiga taktik (Threeways Strategy) sebagai perwujudan kegiatan Marketing Public Relations dari strategy Public Relations menurut Ruslan (2010, h.2) agar dapat melaksanakan program dalam mencapai tujuan (goals), Dalam penelitian ini Strategi komunikasi yang digunakan di Radio Dalka FM dalam menarik minat pengiklan adalah :

1. Pull Strategy (Menarik)

Seorang public relations memiliki potensi dalam menerapkan suatu taktik untuk menarik perhatian publik dengan berbagai cara guna mengupayakan tercapainya tujuan perusahaan serta peningkatan penjuaan baik barang ataupun jasa.

2. Push Strategy (Mendorong)

Upaya dengan menerapkan taktik mendorong atau merangsang meningkatkan jumlah pembelian sehingga dapat meningkatkan angka penjualan.

3. Pass Strategy (Mempengaruhi)

Sebagai upaya mempegaruhi atau menciptakan opini publik menguntungkan melalui berbagai kegiatan, partisipasi dalam kegiatan kemasyarakatan tanggung jawab sosial serta kepedulian masalah yang berkaitan dengan kondisi dan lingkungannya.

\section{METODE PENELITIAN}

Jenis penelitian ini adalah penelitian kualitatif dengan pendekatan deskriptif analisis. Penelitian deskriptif analisis merupakan penelitian yang bertujuan untuk mengungkapkan fakta yang sudah ada dan mendeskriptifkan sesuai fenomena. Menurut Usman dan Purwono (2009, h.129) pengertian dari penelitiaan deskriptif adalah menggambarkan atau melukiskan sesuatu hal, yang berupa gambar-gambar atau foto-foto yang didapat dari data lapangan atau peneliti menjelaskan hasil penelitian dengan kata-kata, dan keduanya dalam penelitian dapat digunakan agar saling melengkapi.

Melalui metode ini penulis akan menggambarkan masalah yang dibahas berdasarkan datadata yang relevan diperoleh serta menafsirkan data-data yang dimaksud sebagai suatu proses analisa untuk mencari relevansi antar variabel. Penelitian akan mendeskripsikan fakta dan data tentang Strategi Komunikasi marketing Radio Dalka FM Meulaboh Dalam Meningkatkan Jumlah Pemasang Iklan.

Cara pengambilan informan dalam penelitian ini ialah dengan teknik purposive sampling (pengambilan sampel dengan tujuan).Purposive sampling menurut Sugiyono (2009, h.85) adalah teknik penentuan sampel dengan petimbangan tertentu seperti orang tersebut yang 
dianggap paling tahu tentang apa yang kita harapkan sehingga memudahkan peneliti menjelajahi obyek/situasi sosial yang diteliti.

\section{HASIL DAN PEMBAHASAN Permodalan}

Tabel 4.1

Tarif Iklan Radio Dalka FM

\begin{tabular}{|l|l|l|}
\hline RADIO SPOT & REGULER & PRIME TIME \\
\hline 30 detik & Rp. 30.000 & Rp. 40.000 \\
\hline 45 detik & Rp. 40.000 & Rp. 60.000 \\
\hline 60 detik & Rp. 60.000 & Rp. 80.000 \\
\hline & & \\
\hline Time Signal & Rp. 60.000 & \multirow{2}{*}{ PER 1 MENIT } \\
\cline { 1 - 2 } & Rp. 30.000 & \\
\hline
\end{tabular}

Tabel 4.2

Data Pamasang Iklan di Radio Dalka 101,3 Dalka FM

\begin{tabular}{|c|c|c|}
\hline Data Tahun 2015 & Data Tahun 2016 & Data Tahun 2017 \\
\hline Pemasang Iklan & Pemasang Iklan & Pemasang Iklan \\
\hline $\begin{array}{l}\text { 1. Pemda Kantor Bupati } \\
\text { 2. Satpol Pp } \\
\text { 3. Bakopi } \\
\text { 4. Hoki Celular } \\
\text { 5. Kusti-Kusti } \\
\text { 6. Kopi Aceh } \\
\text { 7. Murni Gigi } \\
\text { 8. Rasa-Rasa Resto } \\
\text { 9. Ud. Get Taniaga } \\
\text { 10. Galaxi Celular } \\
\text { 11. Fortuna Cell } \\
\text { 12. Bina Flapon } \\
\text { 13. Jne } \\
\text { 14. Bri } \\
\text { 15. Nona Gebrina } \\
\text { 16. Toko Lucky Elektro } \\
\text { 17. Bimbel Tugu } \\
\text { 18. Akbid Meuligo } \\
\text { 19. Jasa Raharja } \\
\text { 20. Toko Iksan Jaya } \\
\text { 21. Indah Galery } \\
\text { 22. Toko Usaha Family } \\
\text { 23. Bakso Tiga Saudara } \\
\text { 24. Bakso Pak Agus } \\
\text { 25. Rs Harapan Sehat }\end{array}$ & $\begin{array}{ll}\text { 1. } & \text { Pemda Kantor Bupati } \\
\text { 2. } & \text { Satpol Pp } \\
\text { 3. } & \text { Bakopi } \\
\text { 4. } & \text { Hoki Celular } \\
\text { 5. } & \text { Kusti-Kusti } \\
\text { 6. } & \text { Kopi Aceh } \\
\text { 7. } & \text { Murni Gigi } \\
\text { 8. } & \text { Rasa-Rasa Resto } \\
\text { 9. } & \text { Ud. Get Taniaga } \\
\text { 10. } & \text { Galaxi Celular } \\
\text { 11. } & \text { Fortuna Cell } \\
\text { 12. } & \text { Bina Flapon } \\
\text { 13. } & \text { Jne } \\
\text { 14. } & \text { Bri } \\
\text { 15. } & \text { Nona Gebrina } \\
\text { 16. } & \text { Toko Lucky Elektro } \\
\text { 17. } & \text { Bimbel Tugu } \\
\text { 18. } & \text { Akbid Meuligo } \\
\text { 19. } & \text { Jasa Raharja } \\
\text { 20. } & \text { Toko Iksan Jaya } \\
\text { 21. } & \text { Indah Galery } \\
\text { 22. } & \text { Toko Usaha Family } \\
\text { 23. } & \text { Bakso Tiga Saudara } \\
\text { 24. } & \text { Bakso Pak Agus } \\
\text { 25. } & \text { Rs Harapan Sehat }\end{array}$ & $\begin{array}{ll}\text { 1. } & \text { Pemda Kantor Bupati } \\
\text { 2. } & \text { Satpol Pp } \\
\text { 3. } & \text { Bakopi } \\
\text { 4. } & \text { Hoki Celular } \\
\text { 5. } & \text { Nagan Raya Fashion } \\
\text { 6. } & \text { Kusti-Kusti } \\
\text { 7. } & \text { Kopi Aceh } \\
\text { 8. } & \text { Murni Gigi } \\
\text { 9. } & \text { Rasa-Rasa Resto } \\
\text { 10. } & \text { Ud. Get Taniaga } \\
\text { 11. } & \text { Galaxi Celular } \\
\text { 12. } & \text { Fortuna Cell } \\
\text { 13. } & \text { Bina Flapon } \\
\text { 14. } & \text { Jne } \\
\text { 15. } & \text { Bri } \\
\text { 16. Nona Gebrina } \\
\text { 17. } & \text { Toko Lucky Elektro } \\
\text { 18. } & \text { Bimbel Tugu } \\
\text { 19. } & \text { Akbid Meuligo } \\
\text { 20. } & \text { Jasa Raharja } \\
\text { 21. } & \text { Toko Iksan Jaya } \\
\text { 22. } & \text { Indah Galery } \\
\text { 23. } & \text { Toko Usaha Family } \\
\text { 24. } & \text { Bakso Tiga Saudara } \\
\text { 25. } & \text { Bakso Pak Agus }\end{array}$ \\
\hline
\end{tabular}




\begin{tabular}{|c|c|c|}
\hline $\begin{array}{l}\text { 26. Star Ponsel } \\
\text { 27. Ayam Penyet Pak Ulis } \\
\text { 28. Toko Kana Murah } \\
\text { 29. Toko Spot Center } \\
\text { 30. Toko Kubuota }\end{array}$ & $\begin{array}{l}\text { 26. Star Ponsel } \\
\text { 27. Ayam Penyet Pak Ulis } \\
\text { 28. Toko Kana Murah } \\
\text { 29. Toko Spot Center } \\
\text { 30. Toko Kubuota } \\
\text { 31. Bpjs Kesehatan } \\
\text { 32. Bpjs Ketenagakerjaan } \\
\text { 33. Pegadaian } \\
\text { 34. Bank Aceh } \\
\text { 35. Inti Tani } \\
\text { 36. Gelora }\end{array}$ & $\begin{array}{ll}\text { 26. } & \text { Rs Harapan Sehat } \\
\text { 27. } & \text { Thya Salon } \\
\text { 28. } & \text { Star Ponsel } \\
\text { 29. } & \text { Ayam Penyet Pak Ulis } \\
\text { 30. } & \text { Toko Kana Murah } \\
\text { 31. } & \text { Toko Spot Center } \\
\text { 32. } & \text { Toko Kubuota } \\
\text { 33. } & \text { Bpjs Kesehatan } \\
\text { 34. } & \text { Bpjs Ketenagakerjaan } \\
\text { 35. } & \text { Pegadaian } \\
\text { 36. } & \text { Bank Aceh } \\
\text { 37. } & \text { Inti Tani } \\
\text { 38. } & \text { Gelora } \\
\text { 39. Pln } \\
\text { 40. } \text { Bio Aktiva } \\
\text { 41. } \text { Garuda Reklame } \\
\text { 42. } \text { Sinar Baru Dg Printing } \\
\text { 43. } \text { Brunai Elektronik } \\
\text { 44. } \text { Sinar Baru Keramik } \\
\text { 45. } & \text { Dialer } \\
\text { 46. } & \text { Zahwa Fashion } \\
\text { 47. } & \text { Mall Fashion } \\
\text { 48. } & \text { Indah Fashion }\end{array}$ \\
\hline
\end{tabular}

Dari data di atas terlihat mayoritas pemasang iklan dari tahun 2015-2017 memperpanjang pemasangan iklan dari tahun ke tahun untuk lebih cepat menarik perhatian konsumen dan pelanggan.Pada tahun 2015 terdapat 30 iklan yang terpasang di Radio Dalka.Kemudian pada tahun 2016 jumlah pemasang iklan meningkat menjadi 36 iklan.Dan pada tahun 2017 pengunjung kembali meningkat menjadi 48 iklan.Pemasang iklan tersebut berjumlah lebih banyak dari tahun ke tahun.

Meskipun karakter pengiklan berbeda satu dengan yang lainnya, pada intinya untuk proses pengenalan radio Dalka FM kepada pengiklan atau penerapan strategi komunikasi yang digunakan radio Dalka FM itu sama saja, tentunya ada tahapan-tahapan yang dilakukan radio Dalka FM, seperti yang dijelaskan oleh Surani mengenai bagaimana strategi yang dilakukan Dalka FM untuk mendapatkan pengiklan:

"kalau kita lebih kepada pendekatan personalnya yang diutamakan, dalam hal pemasangan iklan itu lebih kepada mengakrabkan kita dengan para calon pemasang iklan, kita juga melakukan pendekatan melalui pertemuan langsung atau face to face, memberikan brosur, profile Dalka, sehingga dapat mengakrabkan hubungan yang terbina satu sama lain, semua ini diharapkan ada sebuah ikatan pertemanan yang lebih erat" (hasil wawancara 09 januari 2018, pukul 11:00 wib)

Dari hasil wawancara di atas menjelaskan bahwa strategi untuk mendapatkan pegiklan pihak radio Dalka FM lebih mengakrabkan diri kepada perusahaan-perusahaan, dengan cara memperluas perkenalan bertemu secara langsung mendatangi perusahaan pengiklan untuk menjelaskan mekanisme kerjasama dengan radio Dalka FM. Selanjutnya dari hasil wawancara dengan Surani mengenai aktivitas yang dilakukan dalam melaksanakan strategi komunikasi pemasaran mengatakan bahwa: 
"biasanya berkunjung dan rajin menjalin komunikasi dan silaturahmi dengan calon pengiklan maupun pengiklan, misalnya ada toko baru atau warung kopi, kita kesitu dan menawarkan bagaimana kalau warung ini atau toko ini kita promosikan lagi atau kita buat iklan dengan cara menjelaskan mekanismme kerjasama, memberikan profil radio dan brosur radio". (hasil wawancara 09 januari 2018, pukul 11:00 wib)

Dari keseluruhan penelitian dapat digambarkan data satu tabel sebagai berikut seperti tabel 4.2:

Tabel 4.2 Data Hasil Penelitian

\begin{tabular}{|c|c|c|c|}
\hline \multirow[b]{2}{*}{ No } & \multirow[b]{2}{*}{ Variabel } & \multicolumn{2}{|l|}{ Kesimpulan Jawaban } \\
\hline & & Pengiklan Tahunan & Pengiklan Bulanan \\
\hline 1 & $\begin{array}{l}\text { Awal mula memasang } \\
\text { iklan }\end{array}$ & $\begin{array}{l}\text { Sebagian besar informan } \\
\text { awal mulanya } \\
\text { memasangkan iklan diradio } \\
\text { dalka FM karena mereka } \\
\text { sendiri yang ingin beriklan }\end{array}$ & $\begin{array}{l}\text { Sebagian besar informan } \\
\text { awal mulanya dari radio } \\
\text { Dalka yang menawarkan } \\
\text { untuk memasangkan } \\
\text { iklan }\end{array}$ \\
\hline 2 & $\begin{array}{l}\text { Sudah berapa lama } \\
\text { memasang iklan }\end{array}$ & $\begin{array}{l}\text { Sebagian besar informan } \\
\text { sudah lebih dari satu tahun }\end{array}$ & $\begin{array}{l}\text { Sebagian besar informan } \\
\text { kurang dari satu tahun }\end{array}$ \\
\hline 3 & $\begin{array}{l}\text { Mengapa memilih radio } \\
\text { Dalka FM }\end{array}$ & $\begin{array}{l}\text { Informan menganggap } \\
\text { radio Dalka FM yang } \\
\text { terbaik dan pendengar } \\
\text { banyak anak mudanya }\end{array}$ & $\begin{array}{l}\text { Informan menganggap } \\
\text { radio Dalka FM banyak } \\
\text { pengiklannya, dan juga } \\
\text { pendengarnya banyak } \\
\text { dari kalangan anak muda }\end{array}$ \\
\hline 4 & $\begin{array}{l}\text { Pesan yang ingin } \\
\text { disampaikan }\end{array}$ & $\begin{array}{l}\text { Ingin mempromosikan } \\
\text { produk mereka ke } \\
\text { masyarakat, dan menarik } \\
\text { minat konsumen untuk } \\
\text { membeli produk mereka }\end{array}$ & $\begin{array}{l}\text { Ingin mempromosikan } \\
\text { produk mereka }\end{array}$ \\
\hline 5 & $\begin{array}{l}\text { Apakah tersampaikan } \\
\text { dengan baik }\end{array}$ & $\begin{array}{l}\text { Tersampaikan dengan baik, } \\
\text { konsumen bertambah dan } \\
\text { lebih dikenal oleh } \\
\text { masyarakat luas }\end{array}$ & $\begin{array}{l}\text { Tersampaikan sangat baik } \\
\text { ke masyarakat }\end{array}$ \\
\hline 6 & $\begin{array}{l}\text { Peningkatannya setelah } \\
\text { memasang iklan }\end{array}$ & $\begin{array}{l}\text { Peningkatan pesat, banyak } \\
\text { konsumen atau pelanggan } \\
\text { yang membeli produk } \\
\text { mereka }\end{array}$ & $\begin{array}{l}\text { Banyak peningkatan } \\
\text { penjualan setelah beriklan }\end{array}$ \\
\hline 7 & $\begin{array}{l}\text { Pemasangan iklan } \\
\text { apakah rumit }\end{array}$ & Tidak rumit & $\begin{array}{l}\text { Tidak rumit, tetapi } \\
\text { mempermudah }\end{array}$ \\
\hline 8 & $\begin{array}{l}\text { Pengaruh memasang } \\
\text { iklan }\end{array}$ & $\begin{array}{l}\text { Meningkatnya konsumen } \\
\text { dari dalam daerah dan luar } \\
\text { daerah, banyak konsumen- } \\
\text { konsumen baru }\end{array}$ & $\begin{array}{l}\text { Semakin ramai orang } \\
\text { yang membeli produk } \\
\text { mereka }\end{array}$ \\
\hline 9 & $\begin{array}{l}\text { Cara yang digunakan } \\
\text { radio Dalka sudah } \\
\text { cukup baik }\end{array}$ & Sudah sangat cukup baik & Sudah sangat baik \\
\hline 10 & $\begin{array}{l}\text { Kesepakatan } \\
\text { pembayaran }\end{array}$ & $\begin{array}{l}\text { Kontrak satu bulan sekali } \\
\text { pembayaran }\end{array}$ & $\begin{array}{l}\text { Kontrak satu bulan sekali } \\
\text { pembayaran }\end{array}$ \\
\hline
\end{tabular}




\section{Strategi Komunikasi Marketing Radio Dalka FM}

Penelitian strategi komunikasi pemasaran radio Dalka FM Meulaboh dalam mendapatkan iklan ini dipengaruhi oleh push strategy (strategi mendorong) dan pull strategy (strategi menarik), push strategy adalah perusahaan memiliki kekuatan untuk mendorong berhasilnya pemasaran, dilakukan dengan memasang iklan diberbagai media cetak, serta melakukan promosi penjualan terbaik kepada calon nasabah ataupun masyarakat luas.

Sedangkan pull strategy (strategi menarik) digunakan oleh produsen untuk mengarahkan aktivitas pemasarannya dalam hal periklanan dan promosi konsumen kearah penggunan produk atau jasa untuk memotivasi masyarakat agar membeli produk. Apabila strategi ini berhasil efektif, permintaan produk dari anggota saluran akan meningkatkan permintaan dari produsen, dengan strategi menarik minat konsumen melalui iklan, akan berdampak pada minat permintaan produk yang meningkat dari masyarakat.

Dalam strategi komunikasi pemasaran menggunakan strategi marketing Public Relation, karena pada strategi komunikasi pemasaran ada kesamaan serta keterkaitan dengan strategi yang diterapkan pada strategi marketing Public Relation.Sesuai dengan pengertian marketing Public Relation menggabungkan tiga strategi untuk melakukan program pencapaian tujuan. Dalam penelitian ini strategi yang digunakan hampir serupa dengan strategi yang digunakan dalam marketing Public Relation, yaitu :

1. Pull strategy (strategi menarik) adalah upaya untuk menarik konsumen (pengiklan) agar memakai produk atau jasa yang dikeluarkan sehingga perolehan dalam pemasaran dapat meningkat.

2. Push strategy (strategi mendorong) adalah upaya untuk merangsang (push) pemakaian jasa dan memberikan nilai tambah (added values) atau kepuasan bagi pelanggan setia yang telah memakai jasa radio.

3. Pass strategy adalah upaya untuk mempengaruhi atau menciptakan opini publik yang menguntungkan, serta upaya perluasan pemasaran (Ruslan,2002:254)

Bagian-bagian dalam Threeways strategy yang dikaitkan dengan kegiatan komunikasi pemasaran yang dilakukan radio Dalka FM meulaboh dalam mendapatkan iklan adalah :

1. Pull strategy, menarik pengiklan agar memakai produk atau jasa yang dikeluarkan atau ditawarkan pihak radio Dalka FM dengan cara memberikan profile kepada perusahaan, mendatangi langsung pihak perusahaan, kemudian menyampaikan keunggulan dari pemasangan iklan diradio Dalka FM.

2. Push strategy, upaya merangsang pemakaian jasa dengan cara menjelaskan mengenai program iklan yang ditawarkan, memberikan bonus spot atau penayangan, memberikan potongan harga untuk iklan sesuai dengan kesepakatan antara pihak radio Dalka FM dengan pihak pengiklan.

3. Pass strategy, upaya mempengaruhi atau menciptakan opini publik yang menguntungkan serta upaya untuk mendukung strategi komunikasi pemasaran demi mencapai tujuan, dengan cara memberikan pelayanan terbaik dari radio Dalka FM sesuai keinginan melalui program iklan yang telah diolah dan diedit oleh radio Dalka FM untuk disampaikan ke publik.

\section{Pull Strategy \\ Personal Selling}

Strategi komunikasi pemasaran yang dilakukan radio Dalka FM untuk menarik keinginan pengiklan pada tahap awal adalah mencari situs-situs perusahaan untuk target pemasaran iklan diradio Dalka FM, situs-situs melalui internet google ataupun melalui data-data perusahaan yang sebelumnya sudah menjalin kerjasama dengan radio Dalka FM sebagai pengenalan melalui situs-situs tersebut pihak marketing radio Dalka FM. Setelah mencari data- 
data mengenai target pengiklan, sales promotion radio Dalka FM mendatangi secara langsung ke perusahaan yang dituju untuk memberikan surat penawaran kerjasama kepada klien calon pengiklan, kemudian memberikan profile radio Dalka FM, untuk proses menjalin kerjasama dengan radio Dalka FM, strategi yang diterapkan juga harus mengandalkan kemampuan berkomunikasi yang tepat, cara penyampaian pesan yang tepat akan menumbuhkan keinginan untuk mengetahui lebih banyak mengenai hal yang disampaikan komunikator, sehingga pada akhirnya memberikan kesesuaian respon yang diberikan komunikator dengan maksud dan tujuan yang diinginkan komunikator, pada tahap awal pendekatan kepada pengiklan.

\section{Advertising}

Pengiklan yang telah bekerjasama dengan radio Dalka FM terbagi dua tipe, yang pertama pengiklan tahunan, klien iklan tahunan ini bertujuan untuk mengiklankan produknya diradio Dalka FM supaya produk mereka lebih dikenal masyarakat luas, dan pelanggan atau konsumen yang berkunjung atau membeli produk mereka lebih meningkat dibanding sebelum memasangkan iklan diradio, produk mereka pun jadi lebih dikenal didalam daerah sampai keluar daerah.

Selanjutnya pengiklan bulanan, pengiklan ini tidak begitu lama memasangkan iklan produk mereka diradio Dalka FM, dikarenakan sudah banyaknya konsumen yang berkunjung atau membeli produk mereka, ataupun hanya ingin memasangkan iklan beberapa bulan saja.

\section{Push Strategy \\ Personal Selling}

Push strategi atau strategi mendorong digunakan pihak marketing radio Dalka FM pada tahapan awal, dimana pihak marketing radio Dalka FM melakukan pendekatan dengan calon pengiklan, pihak sales promotion radio Dalka FM akan menjelaskan mekanisme dan juga tata cara beriklan diradio. Selanjutnya ke tahap penjelasan mengenai pentingnya menggunkaan radio sebagai sarana untuk memperluas publikasi serta keuntungan atau kelebihan yang bisa didapat seperti promosi yang lebih cepat, dan publikasi yang lebih luas, sehingga lebih dapat dikenal oleh masyarakat luas dengan waktu yang singkat. Hingga peningkatan penjualan yang didapat setelah mengiklankan produk atau tepat usaha mereka yang dapat membuat para calon pengiklan tersebut terdorong keinginannya ubtuk mempertimbangkan penawaran kerjasama yang ditawarkan radio Dalka FM.

\section{Sales Promotion}

Sales promotion atau promosi penjualan yang ditawarkan oleh pihak radio Dalka FM dengan cara menawarkan berbagai jenis iklan diradio Dalka FM disesuaikan dengan penawaran iklan dan harga iklan yang telah ditentukan oleh pihak radio Dalka FM. Untuk menarik minat pengiklan bagi pengiklan yg sudah tahunan radio Dalka memberikan spot tambahan untuk pengiklan yang telah lama memasangkan iklan produknya.

\section{Pass Strategy}

\section{Public Relations}

Strategi komunikasi yang digunakan radio Dalka FM sebagai radio swasta, berusaha untuk bekrjasama dengan para pengiklan dengan baik serta menjaga hubungan kerjasama agar dapat berkelanjutan dengan memberikan penawaran dan pelayanan sebaik mungkin melalui mekanisme pembuatan iklan diradio Dalka FM. Radio Dalka FM menjaga keakraban dengan para pendengar setia agar tercipta sebuah kedekatan antara pihak radio dengan pendengarnya yaitu dengan cara membuka mengadakan event-event untuk menciptakan citra positif kepada masyarakat. 


\section{SIMPULAN}

Berdasarkan penelitian yang dilakukan diradio Dalka FM mengenai strategi komunikasi radio Dalka FM meulaboh dalam meningkatkan jumlah pemasang iklan menyimpulkan :

Strategi komunikasi pull strategy yang diterapkan oleh Dalka FM adalah dengan mencari sasaran calon pengiklan, kemudian mengirimkan profile radio Dalka FM yang didalamnya didesain semenarik mungkin. Strategi lainnya adalah dengan mencantumkan harga iklan. Hal ini dimaksudkan agar pengiklan tersebut menjadi tertarik untuk menghubungi dan merespon surat penawaran tersebut, atau dengan mengunjungi langsung tempat usaha calon pengiklan atau face to face lalu melakukan pendekatan untuk menawarkan pemasangan iklan secara langsung.Push strategy untuk mendorong ketertarikan pengiklan menjadi keinginan untuk bekerjasama adalah dengan memberikan bonus-bonus spot atau penayangan untuk pengiklan. Pass strategy untuk memperluas pemasaran dan menciptakan opini publik yang positif adalah dengan mengadakan acara on air dan off air, mengadakan event-event berupa kegiatan lapangan untuk mendekatkan diri ke masyarakat.

\section{REFERENSI}

Asep Syamsul M. 2009. Jurnalistik Terapan. Bandung: Batic Press.

Cangara, Hafied. 2006. Pengantar Ilmu Komunikasi. Jakarta: PT. Raja Grafindo. Persada.

Effendy, Onong Ujhana. 2011. Ilmu Komunikasi, Teori dan Praktek. Bandung: PT. Remaja Rosdakarya

Effendy, Onong Ujhana. 2003. Ilmu, Teori dan Praktek Komunikasi. Bandung: PT. Citra Aditya Bakti

Effendy, Onong Uchjana. 1993. Ilmu, Teori dan Praktek Komunikasi. Bandung: PT. Citra Aditya Bakti.

George, A. Stener. 2008. Sistem Informasi Manajemen. Yogyakarta: Andi.

Imam dan Siswandi.2007. Aplikasi Manajemen Perusahaan Analisis Kasus dan Pemecahannya. Jakarta: Mitra Wacana Media.

Morissan. 2011. Manajemen Media Penyiaran: Strategi Mengelola Radio dan Televisi. Jakarta: Kencana Prenada Media Group.

Muhtadi. 1999. Jurnlistik (Pendekatan teori dan Praktik). Jakarta: PT. Logos Wacana Ilmu.

Nurjaman dan Umam. 2012. Komunikasi dan Public Relations. Bandung: Pustaka Setia.

Rangkuti.2009. Strategi Promosi yang Kreatif. Jakarta: Gramedia Pustaka Utama.

Ruslan.2010. Manajemen Public Relations dan Media Komunikasi. Jakarta: PT. Raja Grafindo Persada.

Sugiyono. 2009. Metode Penelitian Kuantitatif Kualitatif \& RND. Bandung: Alfabeta.

Usman dan Purnomo Setiadi Akbar, 2009.Metodologi Penelitian Sosial. Jakarta: Bumi Aksara. 